\title{
Using Masculinity to Stop Sexual Violence: Must Women Be Weak for Men to Be Strong?
}

My Masculinity Helps. By Marc A. Grimmett and David Hambridge, North Carolina Coalition Against Sexual Assault, 2013. 32 min. Price provided upon request. www.mymasculinityhelps.com/about/about-the-film/

\author{
Kristine M. Chapleau \\ chapleau@iupui.edu \\ Department of Psychiatry \\ Indiana University School of Medicine \\ Indianapolis, IN 46202
}

This is the author's manuscript of the article published in final edited form as: 
Using Masculinity to Stop Sexual Violence: Must Women Be Weak for Men to Be Strong? My Masculinity Helps. By Marc A. Grimmett and David Hambridge, North Carolina Coalition Against Sexual Assault, 2013. 32 min. Price provided upon request. www.mymasculinityhelps.com/about-the-film/

The film, My Masculinity Helps, targets a U.S. audience and this review cites research that used U.S. samples unless otherwise noted. Sexual violence has long been considered a women's issue, and recent campaigns have rightly broadened the view of sexual violence as also a men’s problem (e.g., Banyard, Plante, \& Moynihan, 2004). Men, compared to women, are more likely to dismiss sexual violence, blame the victim, and sympathize with the perpetrator (Suarez \& Gadalla, 2010). Not only is this true when the victim is female but also when the victim is male (Struckman-Johnson \& Struckman-Johnson, 1992). Moreover, African American men, compared to White men, have been found to endorse even more victim-blaming attitudes (Giacopassi \& Dull, 1986; Varelas \& Foley, 1998). This difference may be due to systemic disparities in education and socioeconomic level (Nagel, Matsuo, McIntyre, \& Morrison, 2005) but, although yet untested, could also be related to how African American boys and men are undeservedly depicted in the media as threatening, promiscuous, and rapacious (Oliver, 2003; Rome, 2004). Because sexual violence affects both women and men, and also maintains gender inequality worldwide (Yodanis, 2004), enlisting men’s help to end sexual violence is critical.

The educational film, My Masculinity Helps, aims to address these problems by (a) connecting sexual violence with gender inequality, (b) increasing men’s empathy toward rape survivors, (c) providing a counter-narrative for African American men by depicting them as models of prosocial behavior, and (d) teaching men how to support a survivor. This film was funded by a grant awarded to the North Carolina Coalition Against Sexual Assault (NCCASA; 
www.nccasa.org) and was created by Marc A. Grimmett and David Hambridge. The film is 32 minutes long and each of the nine chapters runs from between 2 to 8 minutes. Chapters 2, 3, and 4 define sexual assault, rape, and consent, respectively. Chapter 5 examines men’s greater authority in institutions and thus men have a responsibility to address sexual violence. Chapter 6 examines how objectifying women contributes to oppression and sexual violence. Chapters 7, 8, and 9, address ways to intervene, support a survivor, and prevent sexual violence. Definitions and statistics are presented artfully in large, animated text. The film is short enough to be viewed in its entirety or educators can stop the video to discuss topics between the sets of chapters listed above. The chapters, however, flow seamlessly with a voiceover at the end of one chapter connecting with an image in the following chapter, so educators should be very familiar with the content if they choose to stop the video for discussion. It is important that educators present this to an all-male audience as this makes the intervention more effective than when presented to a coeducational audience (Brecklin \& Forde, 2001).

To assess the likelihood of My Masculinity Helps meeting its goals, it was compared to The Men’s Program (Foubert, 2010; www.oneinfourusa.org/themensprogram.php), an hour-long program with a video (One in Four, Inc., 2010) which has been shown to reduce men’s rape myth acceptance and likelihood to rape, as well as increase men's willingness to intervene when they witness sexual violence (e.g., Langhinrichsen-Rohling, Foubert, Brasfield, Hill, \& ShelleyTremblay, 2011; Schewe, 2002). Like The Men’s Program, My Masculinity Helps wisely approaches men and boys as bystanders with the potential to intervene (e.g., Foubert \& Perry, 2007; Schewe, 2007), rather than as predators with the potential to rape (e.g., Scheel, Johnson, Schneider, \& Smith, 2001). My Masculinity Helps defines demeaning comments about women as “slurs,” and this not only connects sexual violence with gender inequality, but connects 
sexism with racism. Grimmett and Hambridge outline the steps of how to intervene and they address the issue of pluralistic ignorance - that many men think that disrespecting women is wrong, but are afraid to correct another man’s disrespectful behavior, and their silence creates the illusion of unanimity. Instead, African American male leaders in the film encourage young men to recognize that trivializing women is in itself a form of violence and to have the "boldness" to do something about it.

To increase men’s empathy, the chapters that feature a survivor’s story are arranged such that a male bystander first describes his experience of hearing a survivor disclose being sexually assaulted or raped. The male bystander expresses sadness as well as having an "awakening moment” at the gravity and pervasiveness of sexual violence. Placing the male bystander's experience first demonstrates how male audience members should emotionally react to the subsequent story by the survivor. Three survivors' stories are presented, respectively, by an African American woman (sexual orientation unknown), a heterosexual White woman, and a homosexual African American man. The survivors’ stories involve circumstances that are common and often associated with victim blaming (e.g., drinking alcohol; Kahn et al., 1994) and the film emphasizes that, no matter what the circumstances, no one forfeits their right to refuse sex. Nonetheless, this film differs from The Men's Program and runs against evidence showing that female survivors’ stories actually increase men’s rape myth acceptance (Schewe, 2002). Furthermore, although the film challenges the myth that male survivors are impervious to the effects of sexual assault (Struckman-Johnson \& Struckman-Johnson, 1992), the only male survivor depicted is homosexual which could unintentionally reinforce the myth that male-onmale rapes are typically perpetrated by gay men and that male survivors must also be gay (Stermac et al., 2004). A better choice would be to feature a heterosexual male survivor's story 
first: it teaches men how it would feel to be raped, and that perpetrators are often heterosexual and use rape to control other heterosexual men (Foubert \& Newberry, 2006). Depicting maleon-male rape has been shown to increase men's understanding about rape, evoke more empathy for female survivors, lower rape myth acceptance, improve bystander interventions, and reduce rape proclivity (Foubert \& Newberry, 2006; Foubert \& Perry, 2007; Langhinrichsen-Rohling et al., 2011; Schewe, 2002) up to 2 years post-program (e.g., Foubert, Godin, \& Tatum, 2010). Further, the effectiveness of The Men's Program has been found in samples of White fraternity members (Foubert \& Newberry, 2006), White college athletes (Foubert \& Perry, 2007), and U.S. Army enlisted soldiers of whom 96 were African American (Foubert \& Masin, 2012). Although Foubert and Masin did not test if the effectiveness of the program varied by ethnicity, it was found to be effective in a small sample $(n=36)$ of African American, Latino, and Asian American college men (Foubert \& Cremedy, 2007).

My Masculinity Helps, by comparison, specifically targets an African American male audience (Heppner et al., 1999; Schewe, 2007) and aims to provide a counter-narrative of African American masculine identity (Roberts-Douglass \& Curtis-Boles, 2013); this film effectively meets this aim. Grimmett and Hambridge show African American boys playing basketball and discussing why it is wrong to objectify and sexually harass women; an African American barber discussing with his client how to solve young men's lack of respect for women; African American men in church holding young children in their arms. Although a concern could be that these settings fail to show the breadth of African Americans’ interests and experiences, pairing these stereotypic settings with counter-stereotypic attitudes and behaviors can decouple negative stereotypes about African American men (see Blair et al., 2001). Moreover, marketing research has found that African American men tend to respond positively 
to health messages that are embedded in stereotypic settings (e.g., Friedman et al., 2012). In particular, the barbershop is considered culturally important to African Americans (Wood \& Brunson, 2010) and has been used by community health organizers as a trusted setting to influence African American men to engage in various health behaviors (e.g., Victor et al., 2009). Similarly, Grimmett and Hambridge cleverly use the image of a barbershop to influence African American men to support rape survivors and oppose gender oppression. The effect is that $M y$ Masculinity Helps will likely engage an African American male audience (Heppner et al., 1999), and decouple negative stereotypes about African American men by depicting the stereotypical Black man as thoughtful caregivers and concerned supporters of women and survivors - an important counter-narrative that can benefit men and women of all ethnicities.

Whereas My Masculinity Helps creates a solid counter-narrative for African American men, it sticks to a typical narrative for women, and rape survivors of both genders. Men are enlisted to support women because of men's relationships to women as fathers, husbands, friends, etc. However, these examples also suggest that women's value primarily lies in their relationship with men, as opposed to having value in their own right. For example, after helping a female survivor the male professor appears to be most moved by her father's tearful appreciation. Furthermore, men are portrayed as having more societal and physical power than do women. Men’s bodies are more often portrayed as strong, athletic, and in control (e.g., playing basketball, running, skateboarding - even the young boy demonstrates some remarkable dance skills), whereas women's (and survivors') bodies are portrayed as static, uncomfortable, and needing to be carried on the shoulders of someone stronger. For example, the women in a yoga class, including the instructor, assume poses tremulously and at one point the women in the class are shown lying on their backs, motionless, with their eyes covered. Another woman (a 
survivor) rides a horse, but not strenuously, and a young girl walking needs to be carried. This depiction of men as strong and women as weak carries over into how survivors are depicted. Survivors are shown engaging in activities that are stereotypically associated with healing (e.g., yoga, horseback riding), compared to men who are shown being physically active for their own enjoyment. Tellingly, the male survivor is shown doing an activity that is physically passive and related to healing (i.e., writing in a journal), and this may unfortunately communicate that the male survivor has been feminized (Bourdieu, 2001). Although combatting sexual violence and gender inequality should be a joint effort between women and men, enlisting men’s help through the stereotype that women (and male survivors) are weak runs the risk of inadvertently reinforcing men’s paternalism toward women (Glick \& Fiske, 1996). Although there is slight evidence that paternalism is associated with less acceptance of rape myths, paternalism is closely associated with other forms of sexism that correspond with higher rape myth acceptance (Chapleau et al., 2007).

By portraying women as dependent on men, the message about how men can best help survivors may be mixed. On the positive side, the film states that men help when they listen to and believe the survivor, express concern, offer resources, and let the survivor direct the healing process. However, the line between being supportive and authoritative becomes blurred when one survivor says that her friends "pushed me to get help” and a male professor, upon one of his students telling him that she was raped, directed this student to continue coming to class, make eye contact with him at each class to let him know she was attending, and to get counseling. Although these interventions were reported to be helpful to the survivors, this combined with the message that "all men have the authority" to help, could send a mixed message to the audience 
about how directive men should be in helping a survivor. Educators may want to assess audience members' understanding of how to support a survivor and provide additional examples.

\section{Conclusion}

My Masculinity Helps is an artfully presented film that is interesting to watch and is short enough to be presented in one sitting. The male bystanders and survivors' stories are compelling and the film raises several issues that are worthy of discussion, such as the link between sexual violence and sexual harassment, and the link between sexism and racism. This film shows enlightened information coming from African American men in stereotypical contexts, and this has a high potential to alter negative stereotypes about African American men and boys. For this reason, although this film's target audience is African American boys and men, it could also be presented to all-male and all-female groups of other ethnicities. However, this film is less successful in how it presents women and survivors of both genders and could reinforce benevolent stereotypes about women and men. Additionally, My Masculinity Helps uses male bystanders to model appropriate reactions to female survivors' stories; whether this strategy is enough to counteract the effect of female survivors' stories increasing men’s rape myth acceptance (e.g., Schewe, 2002) is unknown. Educators who decide to show this film may want to present a story of a heterosexual male survivor beforehand, and afterwards discuss how this film affects their view of women and male survivors to determine if masculinity, in the form of paternalism, actually helps. 


\section{Acknowledgements}

The author thanks Kizzie Walker at Syracuse University Counseling Center for her helpful comments.

Compliance with Ethical Standards No funding was provided for this work; there are no conflicts of interest (financial or nonfinancial); there was no research involving human participants and/or animals. 


\section{References}

Banyard, V. L., Plante, E. G., \& Moynihan, M. M. (2004). Bystander education: Bringing a broader community perspective to sexual violence prevention. Journal of Community Psychology, 2, 61-79. doi: 10.1002/jcop.10078

Blair, I. V., Ma, J. E., \& Lenton, A. P. (2001). Imagining stereotypes away: The moderation of implicit stereotypes through mental imagery. Journal of Personality and Social Psychology, 81, 828-841. doi: 10.1037//0022-3514.81.5.828

Bourdieu, P. (2001). Masculine Domination. Stanford, CA: Stanford University Press.

Brecklin, L. R., \& Forde, D. R. (2001). A meta-analysis of rape education programs. Violence and Victims, 16, 303-321.

Chapleau, K. M., Oswald, D. L., \& Russell, B. L. (2007). How ambivalent sexism toward women and men support rape myth acceptance. Sex Roles, 57, 131-136. doi: 10.1007/s11199-007-9196-2

Foubert, J. D. (2010). The Men’s Program: Peer educator’s manual. Retrieved from http://www.oneinfourusa.org/products.php\#books

Foubert, J. D., \& Cremedy, B. J. (2007). Reactions of men of color to a commonly used rape prevention program: Attitude and predicted behavior changes. Sex Roles, 57, 137-144. doi: 10.1007/s11199-007-9216-2

Foubert, J. D., Godin, E. E., \& Tatum, J. L. (2010). In their own words: Sophomore college men describe attitude and behavior changes resulting from a rape prevention program 2 years after their participation. Journal of Interpersonal Violence, 25, 2237-2257. doi:

$10.1177 / 0886260509354881$ 
Foubert, J. D., \& Masin, R. C. (2012). Effects of The Men’s Program on U.S. Army soldiers' intentions to commit and willingness to intervene to prevent rape: A pretest posttest study. Violence and Victims, 27, 911-921. doi: 10.1891/0886-6708.27.6.911

Foubert, J. D., \& Newberry, J. T. (2006). Effects of two versions of an empathy-based rape prevention program on fraternity men's survivor empathy, attitudes, and behavioral intent to commit rape or sexual assault. Journal of College Student Development, 47, 133-148. doi: 10.1353/csd.2006.0016

Foubert, J. D., \& Perry, B. C. (2007). Creating lasting attitude and behavior change in fraternity men and male student athletes: The qualitative impact of an empathy based rape prevention program. Violence Against Women, 13, 70-86. doi: 10.1177/1077801206295125

Friedman, D. B., Hooker, S. P., Wilcox, S., Burroughs, E. L., \& Rheaume, C. E. (2012). African American men’s perspectives on promoting physical activity: "We're not that difficult to figure out!” Journal of Health Communication, 17, 1151-1170. doi: 10.1080/10810730.2012.665424

Giacopassi, D. J., \& Dull, R. T. (1986). Gender and racial differences in the acceptance of rape myths within a college population. Sex Roles, 15, 63-75. doi:10.1007/BF00287532

Glick, P., \& Fiske, S. T. (1996). The ambivalent sexism inventory: Differentiating hostile and benevolent sexism. Journal of Personality and Social Psychology, 70, 491-512. doi: 10.1037/0022-3514.70.3.491

Heppner, M. J., Neville, H. A., Smith, K., Kivlighan, D. M., \& Gerhshuny, B. S. (1999). Examining immediate and long-term efficacy of rape prevention programming with racially diverse college men. Journal of Counseling Psychology, 46, 16-26. doi: 10.1037/00220167.46.1.16 
Langhinrichsen-Rohling, J., Foubert, J. D., Brasfield, H. M., Hill, B., \& Shelley-Tremblay, S. (2011). The Men’s Program: Does it impact college men’s self-reported bystander efficacy and willingness to intervene? Violence Against Women, 17, 743-759. doi:

$10.1177 / 1077801211409728$

Kahn, A. S., Mathie, V. A., \& Torgler, C. (1994). Rape scripts and rape acknowledgement. Psychology of Women Quarterly, 18, 53-66. doi: 10.1111/j.1471-6402.1994.tb00296.x

Nagel, B., Matsuo, H., McIntyre, K. P., \& Morrison, N. (2005). Attitudes toward victims of rape: Effects of gender, race, religion, and social class. Journal of Interpersonal Violence, 20, 725737. doi: 10.1177/0886260505276072

One in Four, Inc. (2010). How to help a sexual assault survivor: What men can do [DVD]. Available from http://www.taylorandfrancis.com/books/details/9780415884297/

Oliver, M. B. (2003). African American men as “criminal and dangerous”: Implications of media portrayals of crime on the "criminalization” of African American men. Journal of African American Studies, 7, 3-18. doi:10.1007/s12111-003-1006-5

Roberts-Douglass, K., \& Curtis-Boles, H. (2013). Exploring positive masculinity development in African American men: A retrospective study. Psychology of Men \& Masculinity, 14, 7-15. doi: 10/1037/a0029662

Rome, D. (2004). Black demons: The media's depiction of the African American male criminal stereotypes. Westport, CT: Praeger.

Scheel, E.D., Johnson, E.J., Schneider, M., \& Smith, B. (2001). Making rape education meaningful for men: The case for eliminating the emphasis on men as perpetrators, protectors, or victims. Sociological Practice: A Journal of Clinical and Applied Sociology, 3, 257-278. doi:10.1023/A:1013050219853 
Schewe, P. A. (2002). Guidelines for developing rape prevention and risk reduction interventions. In P. A. Schewe (Ed.), Preventing violence in relationships: Interventions across the life span (pp. 107-136). doi: 10.1037/10455-000

Schewe, P. A. (2007). Interventions to prevent sexual violence. In L. S. Doll, S. E. Bonzo, J. A. Mercy, D. A. Sleet, \& (Eds.), Handbook of injury and violence prevention (pp. 223-240). doi: $10.1007 / \mathrm{b} 136518$

Stermac, L., del Bove, G., \& Addison, M. (2004). Stranger and acquaintance sexual assault of adult males. Journal of Interpersonal Violence, 19, 901-915. doi: $10.1177 / 0886260504266887$

Struckman-Johnson, C., \& Struckman-Johnson, D. (1992). Acceptance of male rape myths among college men and women. Sex Roles, 27, 85-100. doi:10.1007/BF00290011

Suarez, E., \& Gadalla, T. M. (2010). Stop blaming the victim: A meta-analysis on rape mythsrnal Interpersonal Violence, 25, 2010-2035. doi: 10.1177/0886260509354503

Varelas, N., \& Foley, L. A. (1998). Blacks’ and whites’ perceptions of interracial and intraracial date rape. Journal of Social Psychology, 138, 392-400. doi:10.1080/00224549809600391

Victor, R. G., Ravenell, J. E., Freeman, A., Bhat, D. G., Storm, J. S., Shafiz, M., ... Leonard, D. (2009). A barber-based intervention for hypertension in African American men: Design of a group randomized trial. American Heart Journal, 157, 30-36. doi: 10.1016/j.ahj.2008.08.018.

Wood, P. B., \& Brunson, R. K. (2010). Geographies of resilient social networks: The role of African American barbershops. Urban Geography, 31, 228-243. doi: 10.2747/02723638.31.2.228 
Yodanis, C. L. (2004). Gender inequality, violence against women, and fear: A cross-national test of the feminist theory of violence against women. Journal of Interpersonal Violence, 19, 655-675. doi: 10.1177/0886260504263868 